\title{
Analysis and Test of Biomass Briquette and Stoves
}

\author{
Sudip Pandey and Chiranjivi Regmi \\ Nepal Academy of Science and Technology (NAST) \\ Khumaltar, Lalitpur \\ e-mail: environ.sudip@gmail.com
}

\begin{abstract}
Biomass such as agricultural and forestry residues are important resources for energy in Nepal. This biomass can be converted into densified soild biofuel by briquetting fuel technology which can address handling, transportation, and storage problems. In addition, it helps to increase a number of applications and enhance its utilization efficiency. The purpose of this study is to quantify the physical and chemical properties of different biomass, such as sawdust, banana stem, rice straw, etc. and combustion in order to investigate clear options. Additionally, it helps to provide the efficiency of stoves available at Nepal Academy of Science and Technology (NAST) laboratory. Among the feedstock tested, Mikania micrantha char had highest fixed carbon of $45.92 \%$ which clearly shows that it is a good source for biomass briquetting. Out of four stoves tested, Baked Ceramic 4 BHB Stoves had highest efficiency of 33.4\% with Banmara briquettes. The study also showed reduced emission of harmful gases ultimately reducing the indoor air pollution. Thus, with the proper densification these fuels can be used as a substitute for the traditional fuels in domestic as well as industrial application in furnaces, boilers and kilns.
\end{abstract}

Key words: briquetting, fuelwood, improved cookstoves, indoor air pollution

\section{Introduction}

Energy is critically important in development, economic growth, national and regional environmental protection. The efficient production and use of energy in an environmentally sound way is essential to tackle these concerns and lead to sustainable development based on equity, empowerment, environmental harmony and economic efficiency. The overall energy consumption of Nepal is largely dominated by the use of traditional fuels (87.0\%) such as fuelwood (77.7\%), agriculture residue (3.7\%) and animal dung (5.7\%) (WECS 2010). The use of this traditional fuel for household $(\mathrm{HH})$ cooking and heating in poorly ventilated kitchens cause indoor air pollution (IPA). In 2002, IAP was responsible for the death of 7,500 people in Nepal (WHO 2007). Also the social cost of collection of fuelwood is heavy. Women and children had to spend 2-3 hrs a day in the collection of fuelwood (K.C. et al. 2011). Hence, it is important to direct activities to address these problems by providing alternatives and improving the fuels characteristics as well as curtailing harmful emission.
Other major consumers of fuelwood, biomass, etc in Nepal are the industrial boilers, furnace and kilns (World Bank/UNDP 1993). These furnace, kilns and boilers use a variety of fuels ranging from fuelwood, coal, agricultural biomass to even old automobile tires. As there are more than 150 brick kilns operating in Kathmandu valley alone, they are major sources of pollution (Raut 2003).

The uses of these fuels not only lead to deforestation but also to environmental pollution and climatic changes. Smoke, Sulfur dioxide and nitrogen oxides are the major pollutants generated from these fuels (Luo et al. 1999). In search for alternatives to these pollutants Nepal has introduced several alternatives energy sources such as biogas, micro-hydro, kerosene, liquefied petroleum gas (LPG), improved cookstove (ICS), solar/wind technologies, briquettes, etc. Among these alternatives, briquettes based on agriculture residues and forest residues could be an alternative to fuelwood for cooking and other purposes (WECS 2010). One of the objectives of this research is to reduce the harmful emission through the introduction of 
briquettes. In addition, this study tries to analyze the physical and chemical properties of briquettes.

\section{Methodology}

Different biomass briquette and samples were collected and tested in the laboratory of NAST. Proximate analysis (moisture content, ash content, volatile matter content, and fixed carbon content) was carried out according to JIS M 8813 and calorific values of the samples were determined with Toshniwal Digital Bomb calorimeter (Model CC01/M2A). The efficiency of the sample/stove was calculated with standard water boiling test (WBT). Weight of fuel sample burned was measured by weighing the briquette on a balance. The efficiency of stove $(\eta)$ was calculated by employing following formula:

$$
\eta=\frac{M_{1 \times C_{f w} \times \Delta T}+M_{\text {evap }} \times L_{f}}{M_{f} \times H_{f}}
$$

Where,

$M_{1} \quad$ Initial weight of water

$C_{f w} \quad$ Specific heat of water $\quad\left(\mathrm{KJ} / \mathrm{Kg} /{ }^{\circ} \mathrm{C}\right)$

$\Delta T \quad$ Rise in temperature of water

$M_{\text {evap }}$ Mass of water evaporated

$L_{f} \quad$ Latent heat of evaporation of water $(\mathrm{KJ} / \mathrm{Kg})$ $\left(2250 \mathrm{KJ} / \mathrm{Kg}\right.$ at $100^{\circ} \mathrm{C}$ and $10^{5} \mathrm{~Pa}$ )

$M_{f} \quad$ Mass of fuel burned

$H_{f} \quad$ Calorific value of fuel $(\mathrm{KJ} / \mathrm{Kg})$
The smoke numbers of different fuels were measured using Bacharach scale to evaluate the smoke emission of different fuels. Pump with a filter paper was placed over the stove to suck the smoke emission. The spot created on the filter paper after suction of the emission was compared with the standard scale, which begins from 0 to 9 to evaluate the smoke density/emissions. The greater the smoke numbers, the higher would be the smoke emissions. For the breaking strength a tablet of 3mm thickness and $\sim 25 \mathrm{~mm}$ diameter were prepared from the biomass sample. These tablets were tested in a machine to determine the spring back ration.

\section{Result and Discussion Proximate analysis}

The proximate analysis involves the use of simple tests, focused on estimating the main constituents of biomass which have a direct influence on the combustion characteristics, i.e. the moisture content of a biomass, the amount of volatiles, fixed carbon (char) and the amount of ash. For instance, the contribution of flaming and glowing combustion in biomass combustion process depends on the proportion of volatile matter and fixed carbon which together with the moisture content of biomass have a strong influence on the calorific value (RWEDP 1993). The results of proximate analysis are shown in Table 1.

Table 1. Proximate analysis of some biomass sample

\begin{tabular}{|c|c|c|c|c|c|}
\hline S.N & Name of sample & MC (\%) & VMC (\%) & $\mathrm{AC}(\%)$ & FC (\%) \\
\hline 1 & Coal (Hetauda, Nepal) & 14.671 & 17.092 & 28.207 & 40.030 \\
\hline 2 & Low grade coal (Dang, Nepal) & 1.263 & 62.055 & 13.640 & 23.042 \\
\hline 3 & Alnus nepalensis (Utis) saw dust, & 10.48 & 68.93 & 1.05 & 19.54 \\
\hline 4 & Mikania micrantha char & 3.448 & 31.464 & 19.12 & 45.921 \\
\hline 5 & Eupatorium adenophorum & 9.22 & 73.62 & 1.89 & 15.27 \\
\hline 6 & Water hycinth & 14.13 & 76.06 & 6.16 & 3.65 \\
\hline 7 & Pine needles (Tukuche) & 13.210 & 64.877 & 3.757 & 18.156 \\
\hline 8 & BHB (Department store) & 5.266 & 11.488 & 61.429 & 21.818 \\
\hline 9 & Wheat straw & 9.21 & 73.28 & 4.21 & 13.30 \\
\hline 10 & Coffee husk & 7.027 & 76.241 & 0.978 & 16.254 \\
\hline 11 & Lantana camera & 12.12 & 66.99 & 4.29 & 16.58 \\
\hline 12 & Maize stalk & 10.42 & 68.13 & 4.41 & 17.02 \\
\hline 13 & Rice straw (Khumaltar) & 18.05 & 53.03 & 16.25 & 12.67 \\
\hline 14 & Banana stem & 35.95 & 36.21 & 10.43 & 17.38 \\
\hline 15 & Rwanda peat char (Grinded) & 6.218 & 12.959 & 46.447 & 34.376 \\
\hline
\end{tabular}

Note: MC - Moisture content, VMC - Volatile matter content, AC - Ash content, FC - Fixed carbon 
Sudip Pandey and Chiranjivi Regmi/Analysis and Test of Biomass.......

From the results of proximate analysis, out of 15 different laboratory samples, 13 had the moisture content within the limit of $15 \%$ recommended by Wilaipon (2008) for the briquetting of agro-residues. Whereas, rice straw (18.05\%) and banana stems (35.95\%) had more moisture content compared to other samples. According to Eriksson and Prior (1990), some materials with up to $20 \%$ moisture content can be classified in a piston press. He further added that moisture content above $10 \%$ might lead to excess steam production which can lead to steam explosion. The differences in material moisture content can cause higher variation in energy requirement than those between materials. Among these tested samples, $M$. micrantha char (45.921\%) and coal from Hetauda, Nepal (40.0\%) had high carbon content compared to others. According to the report published by FAO 1985, fixed carbon content for domestic and industrial purpose can range from $50 \%$ to $95 \%$. Erlinda and Dionco-Adetayo (2001) explained that the charcoal for briquetting from high temperature will be higher in fixed carbon than the charcoal produced at lower temperature. Thus, we can say that Mikania char and Hetauda coal are good for bee-hive briquettes.

\section{Calorific value}

Another most important characteristics of a fuel is its calorific value, that is the amount of energy per kg it gives off when burnt. The calorific value can thus be used to calculate the competitiveness of a processed fuel in a given market situation. Some of the samples tested in the lab are shown in the Table 2 with some of their photographs.

\section{Table 2. Calorific value of different samples}

Water equivalent - $2540.264 \mathrm{Cal} .{ }^{\circ} \mathrm{C}$

\begin{tabular}{ll|l|c}
\hline S.N & Test date & Name of sample & Calorific value (kJ/kg) \\
\hline 1 & 07 January, 2011 & CRUDE OIL (BIODISEL), IOE & 38621.49 \\
2 & 07 January, 2011 & PLASTIC & 45867.14 \\
3 & 13 January, 2011 & BIODISEL (10\%) - B10 & 47756.69 \\
4 & 06 January, 2011 & IOE, TORRIFIED SAMPLE & 23912.03 \\
5 & 06 January, 2011 & RAMCHE COAL 1 & 8186.37 \\
6 & 07 January, 2011 & AJIMARA COAL & 25054.79 \\
7 & 23 December, 2010 & WOOD & 22648.21 \\
8 & 23 December, 2010 & COAL & 11472.75 \\
9 & 23 December, 2010 & BENZOIC ACID & 10635.57 \\
10 & 13 January, 2011 & Briquette sample from NEC & 4973.36 \\
\hline
\end{tabular}
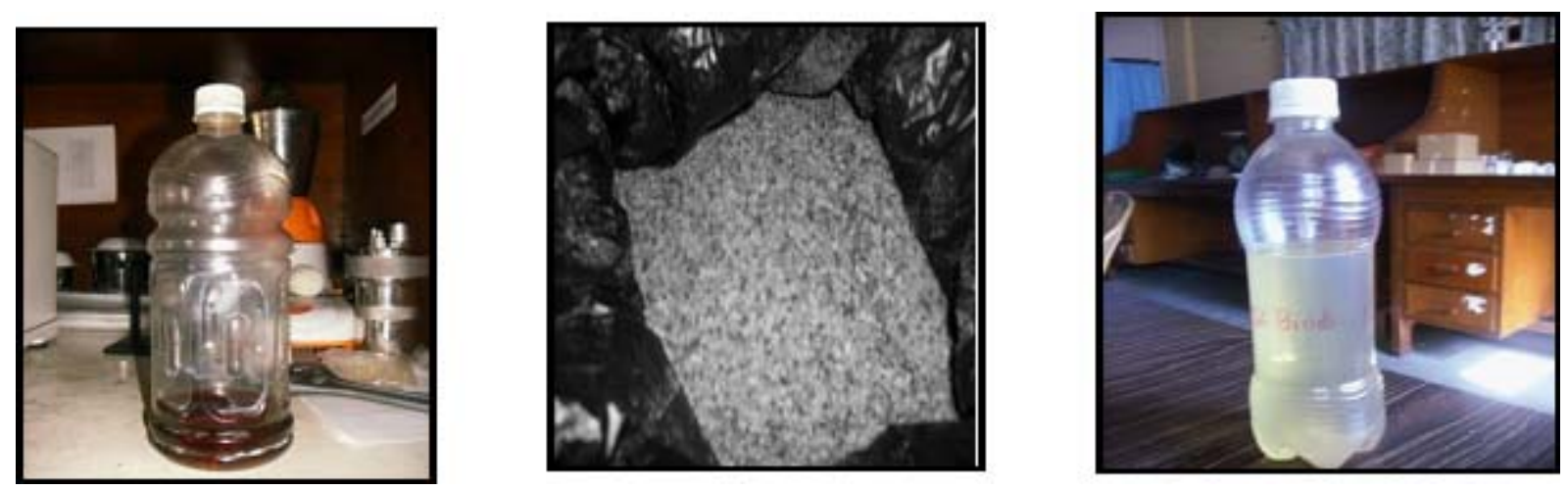

Fig.1. Some of the samples tested in a laboratory to find out calorific values

The higher heating value calculated for fuel samples was $47756.69 \mathrm{~kJ} / \mathrm{kg}$ for Biodisel (B10) and lowest for briquette sample from Nepal Engineering College $(4973.36 \mathrm{~kJ} / \mathrm{kg})$. These energy values are sufficient enough to produce heat required for household cooking and small scale industrial cottage applications. These were also compared well with most biomass energy. For examples, groundnut shell briquette- 12,600 $\mathrm{kJ} / \mathrm{kg}$ (Musa 2007), cowpea- 14,372.93 kJ/kg, and soybeans-12,953 kJ/kg (Enweremadu et al. 2004). 


\section{Efficiency of stoves}

Water boiling test (WBT) was intended to help stove designers to measure how efficiently a stove was used to heat water in a cooking pot. The thermal efficiency of the SCORE stove (Fig.2) was found to be $15.88 \%$. The low efficiency of the stove may be due to the material used i.e. cement. In addition, there was no open passage for the air to flow making the inefficient combustion of fuel. From bacharach smoke index test, the emission from the stove was found to be bad. There was one drawback of this stove that there was no ash remover so it was difficult to continue the burning period for longer period of time. During another study, Madhukar stove (Fig. 3) was found to have thermal efficiency of $25 \%$ with the operation of a fan. The special feature of this stove was that there was external air supply to burn the fuel. The emission from the stove was found to be at satisfactory level. The major drawback of this stove was that there was no ash remover so it was difficult to continue the experiment for long time. Also after, fuel wood changes to ash, it

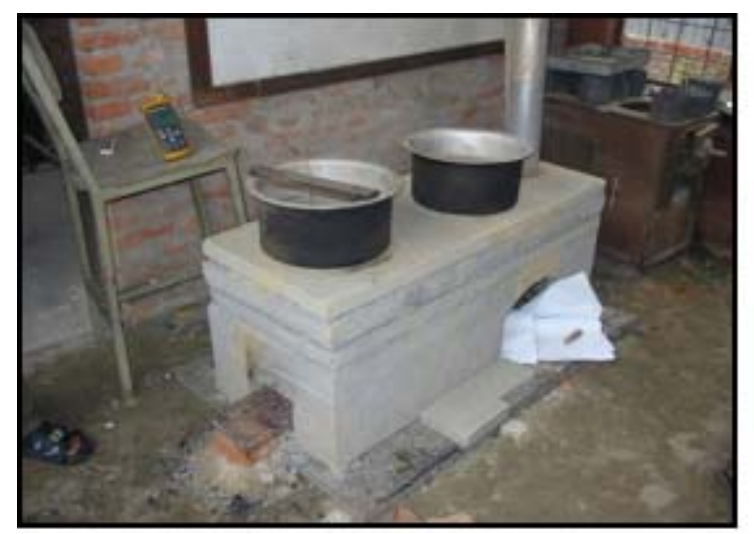

Fig. 2. Score Stove

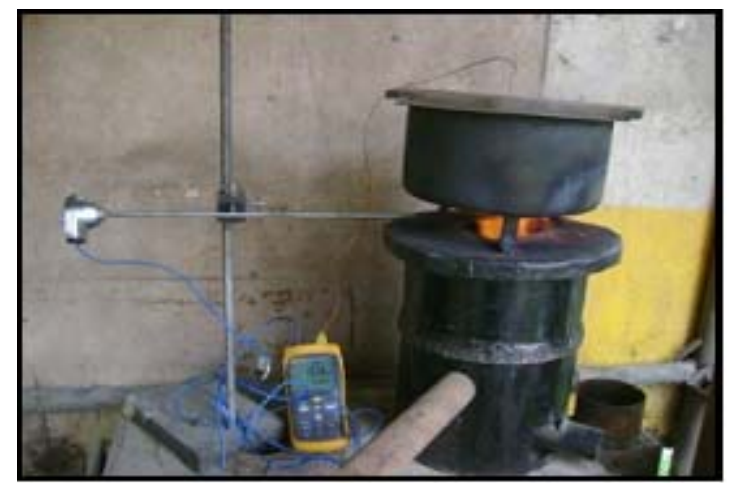

Fig.4. Top lit up draft gasifier stove may enter into the cooking vessel because of air supply.

In another study carried out in the laboratory, top lit up draft (TLUD) gasifier stove (Fig. 4) showed the efficiency of $15.47 \%$ when wood was used as fuel material. This low efficiency may be due to design of a stove. Thus, modification and improvements were necessary for chimney, insulation and air supply system so that its efficiency can be increased. For testing multiple BHB, Ceramic 4 beehive briquette stove (Fig. 5) was used. During testing of these stoves it was observed that the stoves developed cracks getting heated from BHB as they were made from locally available clay. Again, due to its size, it was not possible to transfer conveniently avoiding the damage of stove. To address these problems, baked ceramic 4 BHB stoves was fabricated and tested in the laboratory. From the test, it was observed that the total burning time using 4 BHBs was more than two and half hours with the efficiency of 33.4\% using banmara BHB.

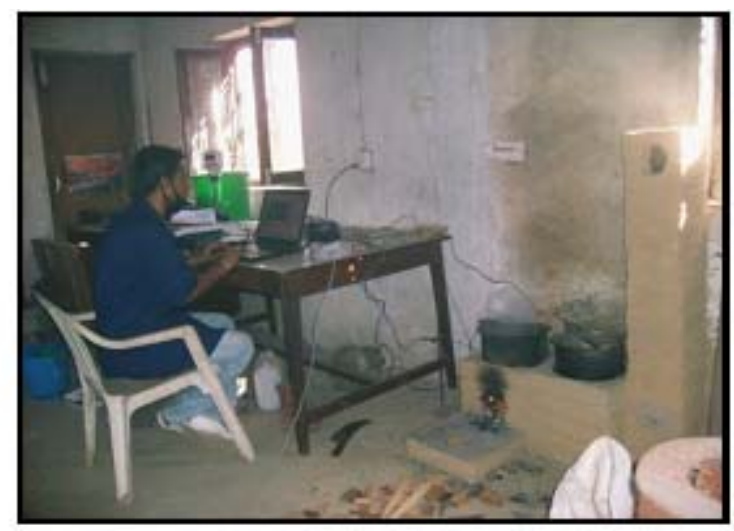

Fig. 3. Madhukar stove

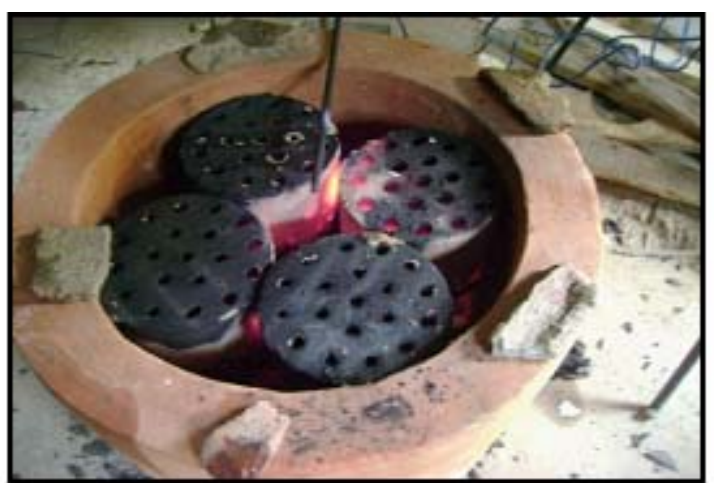

Fig. 5. Baked ceramic 4 BHB stoves 
However, stove consumers neither usefully compare the heat outputs of stoves nor their efficiency. Because it depends on different factors like how open the air vents were during the test or how often the stove was refueled.

\section{Breaking strength}

Breaking strength evaluates the stability and strength of briquette. It also shows the force required to break the prepared briquette. Ultimately, it helps by giving the information for proper handling and transportation of the briquettes to long distance. Table 3 gives the idea about the strength of the briquettes made from M. micrantha char.

From table, we observed that breaking strength increases with the increase in the briquette pressure provided in making the tablet. So, if we make briquette at high pressure then the strength of the briquettes were higher and they were stronger and stable too. However, with increase in briquetting pressure, the cost of briquetting increases very much.

\section{Table 3. Breaking strength of sample}

\begin{tabular}{ll|c|c}
\hline S.N & Biomass & $\begin{array}{l}\text { Pressure (Mpa) } \\
\text { to make tablet }\end{array}$ & $\begin{array}{c}\text { Breaking } \\
\text { strength }\end{array}$ \\
\hline 1 & Mikania micrantha & 5 & 2.41 Newton \\
2 & Mikania micrantha & 10 & 3.56 Newton \\
3 & Mikania micrantha & 15 & 4.05 Newton \\
4 & Mikania micrantha & 20 & 4.70 Newton \\
\hline
\end{tabular}

\section{Conclusion}

Briquettes were produced from variety of feedstock to compare their physical and chemical properties. The physico-mechanical characteristics of biomass raw materials showed the biobriquettes have better combustion with lower amount of smoke emission. The study confirms that medium size feedstock with low moisture content are more efficient compare to other. Efficiency of stoves show 4 ceramic BHB as better compared to others with banmara briquettes. However, comparing efficiency of stoves with each other depend on refueling periods and with the air vents open to varying degrees. Thus, the end users do not really know exact efficiency until the testing is done in specific conditions. The overall study recommends biobriquettes as an alternative fuel as it has lower amount of smoke emission, higher calorific values and ability to burn longer with stable and uniform temperature.

\section{Acknowledgements}

The authors like to thank all the members of the Faculty of Technology, NAST for their support and assistance in carrying out the research work. Special thanks go to Dr. Suresh Kumar Dhungel and Mr. Mukesh Ghimire for their valuable suggestions and inspiration to carry out the work.

\section{References}

Enweremadu, C.C., J.O. Ojediran, J.T. Oladeji and I.O. Afolabi. 2004. Evaluation of energy potential of husks from soy-beans and cowpea. Science Focus. 8: 18-23.

Eriksson, S. and M. Prior. 1990. The briquetting of agriculture of agricultural wastes for fuel. FAO Environment and Energy Paper no. 11. Rome, Italy, 141 pp.

Erlinda, A and Dionco-Adetayo. 2001. Utilization of wood wastes in Nigeria: a feasibility overview. Technovation, 21: 55-66.

FAO. 1985. Industrial charcoal making. Working paper no. 63. Rome, Italy, 133pp.

K.C., S., S. K. Khanal. P. Shrestha and B. Lamsal 2011. Current status of renewable energy in Nepal: Opportunities and challenges. Renewable and Sustainable Energy Reviews. 15: 4107-4117.

Luo, Z and W. Hulscher. 1999. Wood fuel emission. FAO/ RWEDP, Bangkok, Thailand, 16-18.

Musa, N.A. 2007. Comparative fuel characterization of rice husk and groundnut shell briquettes. NJREDI. 6: 2327.

Raut, A.K., 2003. Brick Kilns in Kathmandu Valley: Current status, environmental impacts and future options. Himalayan Journal of Sciences. 1(1): 59-61.

RWEDP. 1993. Improved solid biomass burning cook stoves: A development manual. Field documents no. 44. Bangkok, Thailand, Pp. 16-67.

UNDP. 1993. Nepal: Energy efficiency and fuel substitution in industries: an agenda for action. World Bank/UNDP report no. 158/93, Washington DC, USA, 89 pp.

WECS. 2010. Energy sector synopsis report. Water and Energy Commission Secretariat, Kathmandu, Nepal. 114 pp.

Wilaipon, P. 2008. Density Equation of Bio-Coal Briquette and Quantity of Maize Cob in Phitsanulok, Thailand. American Journal of Applied Sciences. 5(2):1808-1811. 
Nepal Journal of Science and Technology Vol. 14, No. 1 (2013) 115-120 